\title{
Breast cancer screening: How knowledgeable are female staff of a public university?
}

\author{
Nor Afiah MZ, Hejar AR, Looi YK, Lim SJ, Ng CY, and Tong CY \\ Faculty of Medicine and Health Sciences, Universiti Putra Malaysia, Serdang, Selangor, Malaysia
}

\begin{abstract}
Introduction: Breast cancer is the most common cancer among women worldwide and in Malaysia. It has better cure rate if detected early. However, the practice of breast cancer screening in Malaysia is still low. The objective of this study is to determine the knowledge and its associated factors as well as sources of information on breast cancer and breast cancer screening among female staff in a public university in Malaysia. Materials and Methods: This was a cross sectional study conducted in 2005 involving 394 female staff including academic and non-academic staff, which was selected by cluster sampling. A self-administered questionnaire on socioeconomic characteristics and family history of breast cancer was used for data collection. Chi-square Test and Fisher's Exact Test was used for testing an association using SPSS 12.0. Results: The response rate was $84.3 \%$. Only $50.9 \%$ had high knowledge on breast cancer and breast cancer screening and this was significantly associated with occupational status, monthly family income and educational level $(p<0.05)$. The usual source of information was mass media (92.2\%) while the most preferred source is the health team $(71.4 \%)$.

Conclusion: As mass media was a major source of information, all types of mass media could efficiently be utilized to disseminate knowledge by presenting specific programmes associated with breast cancer and breast cancer screening.
\end{abstract}

KEYWORDS: Breast cancer, screening, knowledge, information literacy.

\section{INTRODUCTION}

Breast cancer is the third most common cancer worldwide and the second leading cause of cancer death. It accounts for up to $18 \%$ of all cancer incidences in women worldwide. ${ }^{1}$ There are approximately 1 million new cases in the world each year. ${ }^{1}$ In Malaysia, 3738 female breast cancer cases were reported in 2003, making it the most commonly diagnosed cancer in women. ${ }^{2,3}$ It accounted for up to $31 \%$ of all new cancer cases in women. ${ }^{3}$ Breast cancer is the second leading cause of cancer admissions in the Ministry of Health hospitals in Malaysia and is responsible for $6-8 \%$ of all cancer deaths. It is the fourth leading cause of cancer deaths since $1991 .{ }^{4}$

Screening and early detection of breast cancer in a high risk person based on the features of breast changes will lead to early treatment and better outcome. Breast cancer screening tests are available in government and private clinics and hospitals. Every woman has the opportunity to undergo the screening tests. Yet, the practice of regular screening of breast cancer is still low despite health education programmes held by the government. The Second

\section{Corresponding author;}

Nor Afiah Mohd Zulkefli

Department of Community Health

Faculty of Medicine and Health Sciences

Universiti Putra Malaysia

43400 Serdang, Selangor,

Malaysia.

E-mail: norafiah@medic.upm.edu.my
National Health and Morbidity Survey (NHMS II) data conducted by Ministry of Health Malaysia in 1996 showed that the overall prevalence for breast cancer screening was $46.8 \% .^{5}$ The prevalence of breast self-examination (BSE) was reported to be $34.1 \%$, followed by clinical breast examination (CBE) $31.1 \% .^{10}$ Although mammography was claimed to be the best method to detect breast abnormalities, only $3.8 \%$ of women carried out the procedure. ${ }^{5}$

A study done in 2003 among 185 educated Appalachian women showed that these women believe breast selfexamination leads to early cancer detection but they lacked the knowledge about breast cancer risk factors and screening guidelines, particularly the timing and effective methods of breast self-examination. However, higher level of knowledge on breast self-examination was related to perceived practice proficiency $(r=0.21, p<0.001)$. Those who were more motivated to practice $(r=0.42, p<0.001)$ and those who were taught by health care providers about cancer screening instructions had higher level of knowledge. ${ }^{6}$ Another study also showed that the level of knowledge on breast cancer screening among Chinese American women was low. More than half of 332 Chinese American women had heard of clinical breast examination $(51.8 \%)$, but only one third had heard of mammogram $(32.3 \%)$ and breast self-examination (35.2\%). ${ }^{7}$

Sources of information on breast cancer screening are also important in order to plan the best media to disseminate the information to the public whereby it can also help to increase their knowledge. The main source of information regarding breast self-examination among 122 working women in Medical and Nursing Faculties affiliated to Ain Shams University, Abbassia, Cairo, Egypt was peer group (47.5\%). This is because working women spent most of their time with their 
friends at the work place. Meanwhile, 30.4\% reported acquiring information from mass media (such as TV, radio, newspapers and magazines). Mass media was the most important source of information because $82 \%$ of the working women had improved their level of knowledge on breast self-examination after being exposed to mass media. Thirteen percent of working women acquired the information from books and $9.0 \%$ received the information from health team such as nurses and physicians. ${ }^{8}$

The purpose of this study is to determine the level of knowledge and sources of information on breast cancer screening among female staff in a public university in Malaysia. Female staffs were chosen instead of the general population because the assessment of their level of knowledge could contribute to better understanding on the challenges in providing services to women with regards to breast cancer screening programme. The result may help to strengthen future health programmes on the breast cancer screening activities.

\section{MATERIALS AND METHODS}

This cross-sectional study was conducted in April 2005 in a public university in Malaysia. There were a total of 58 departments in the university. The staffs were able to access health services provided by the Health Center of the university, nearby government clinics and hospitals, and panel clinics. Of the 58 departments, only 15 departments were systematically selected. Cluster sampling of the female academic and non-academic staff in the selected departments were chosen based on the list given by each departments. Sample size was determined based on the WHO manual. ${ }^{9}$

A self-administered questionnaire was used. It was divided into four sections, which comprising information on socioeconomic status, family history, knowledge on breast cancer screening, sources of information and preferred sources of information. There were 8 main questions on knowledge, mainly on symptoms, risk factors, screening and treatment of breast cancer. The knowledge questions were subdivided into 41 questions, so the total questions were 41. Knowledge was categorised into high or low by the median of the total scores. Knowledge was assessed by asking Yes or No questions with 1 point given to each correct answer. A 'Don't know' answer was given 0 points. The full marks were 41. To determine the level of knowledge, a score equal to or above the median was considered to have high knowledge while a score below the median was considered to have low knowledge.

The questionnaire was reviewed by a behavioral scientist. Pre-testing was carried out on 40 women working in the university. Upon completion of the pre-testing, necessary changes were made to the questions according to the feedback from the respondents.

\begin{tabular}{|c|c|c|}
\hline Socioeconomic status & $n$ & $\%$ \\
\hline \multicolumn{3}{|l|}{ 1. Age $(n=331)$} \\
\hline$<30$ years & 131 & 39.6 \\
\hline 30.50 years & 179 & 54.1 \\
\hline$>50$ years & 21 & 6.3 \\
\hline \multicolumn{3}{|l|}{ 2. Race $(n=332)$} \\
\hline Malay & 321 & 96.7 \\
\hline Chinese & 6 & 1.8 \\
\hline Indian & 4 & 1.2 \\
\hline Others & 1 & 0.3 \\
\hline \multicolumn{3}{|l|}{ 3. Religion $(n=332)$} \\
\hline Islam & 323 & 97.3 \\
\hline Buddhist & 3 & 0.9 \\
\hline Hindu & 4 & 1.2 \\
\hline Christian & 2 & 0.6 \\
\hline Others & 0 & 0 \\
\hline \multicolumn{3}{|l|}{ 4. Marital status $(n=331)$} \\
\hline Single & 110 & 33.2 \\
\hline Married & 214 & 64.7 \\
\hline Divorcee & 2 & 0.6 \\
\hline Widow & 5 & 1.5 \\
\hline \multicolumn{3}{|l|}{$\begin{array}{l}\text { 5. Occupational status } \\
(n=332)\end{array}$} \\
\hline Academic staff & 91 & 27.4 \\
\hline Non-academic staff & 241 & 72.6 \\
\hline \multicolumn{3}{|l|}{$\begin{array}{l}\text { 6. Monthly family income } \\
(\mathrm{n}=332)\end{array}$} \\
\hline$<\mathrm{RM1000}$ & 42 & 12.7 \\
\hline RM1000-RM2000 & 93 & 28 \\
\hline RM2001-RM3000 & 65 & 19.6 \\
\hline RM3001-RM4000 & 43 & 13 \\
\hline RM4001-RM5000 & 29 & 8.7 \\
\hline$>$ RM5000 & 60 & 18.1 \\
\hline \multicolumn{3}{|c|}{ 7. Educational level $(n=331$ ) } \\
\hline UPSR & 2 & 0.6 \\
\hline PMR & 12 & 3.6 \\
\hline SPM & 83 & 25.1 \\
\hline STPM/A- & 8 & 2.4 \\
\hline \multicolumn{3}{|l|}{ level/Matriculation } \\
\hline Diploma & 47 & 14.2 \\
\hline Bachelor & 87 & 26.3 \\
\hline Master & 69 & 20.8 \\
\hline PhD & 23 & 6.9 \\
\hline \multicolumn{3}{|l|}{$\begin{array}{l}\text { 8. Family history of breast } \\
\text { cancer ( } n=329)\end{array}$} \\
\hline Yes & 35 & 10.6 \\
\hline No & 294 & 89.4 \\
\hline
\end{tabular}

The questionnaires were distributed personally to the respondents. The respondents were given a period of three days to complete the questionnaires and the completed questionnaires were collected personally. 
Table 2. Distribution of correct and wrong answers on knowledge of breast cancer screening among the respondents

\begin{tabular}{|c|c|c|c|c|c|c|}
\hline \multirow[b]{2}{*}{ Statement } & \multicolumn{2}{|c|}{ Correct } & \multicolumn{2}{|c|}{ Wrong } & \multicolumn{2}{|c|}{ Don't know } \\
\hline & $\mathrm{n}$ & 8 & $\mathrm{n}$ & 8 & $\mathrm{n}$ & $\%$ \\
\hline \multicolumn{7}{|l|}{ 1. Symptoms of breast cancer } \\
\hline a) Lump(s) in the breast & 281 & 84.6 & 32 & 9.6 & 19 & 5.7 \\
\hline b) Nipple retraction & 171 & 51.5 & 65 & 19.6 & 96 & 28.9 \\
\hline c) Bloody discharge from the nipple & 232 & 69.6 & 36 & 10.8 & 64 & 19.3 \\
\hline $\begin{array}{l}\text { d) Puckering of the skin of the } \\
\text { breast }\end{array}$ & 153 & 46.1 & 62 & 18.7 & 117 & 35.2 \\
\hline $\begin{array}{l}\text { e) Swelling of the axillary's lymph } \\
\text { nodes }\end{array}$ & 264 & 79.5 & 34 & 10.2 & 34 & 10.2 \\
\hline f) Weight gain & 154 & 46.4 & 20 & 6 & 158 & 47.6 \\
\hline \multicolumn{7}{|l|}{$\begin{array}{l}\text { 2. Risk factors of breast } \\
\text { cancer }\end{array}$} \\
\hline a) Young age (< 40 years old) & 180 & 54.2 & 78 & 23.5 & 74 & 22.3 \\
\hline $\begin{array}{l}\text { b) Onset of menses before } 12 \text { years } \\
\text { old }\end{array}$ & 85 & 25.6 & 134 & 40.4 & 113 & 34 \\
\hline c) Menopause after 55 years old & 101 & 30.4 & 114 & 34.3 & 117 & 35.2 \\
\hline d) Diets high in fat & 210 & 63.3 & 48 & 14.5 & 74 & 22.3 \\
\hline e) Family history of breast cancer & 287 & 86.4 & 32 & 9.6 & 13 & 3.9 \\
\hline f) Past history of breast cancer & 237 & 71.4 & 80 & 24.1 & 15 & 4.5 \\
\hline g) First pregnancy after 35 years old & 114 & 34.3 & 110 & 33.1 & 108 & 32.5 \\
\hline h) Nulliparity at age of 40 years & 130 & 39.2 & 95 & 28.6 & 107 & 32.2 \\
\hline i) Overweight & 87 & 26.2 & 133 & 40.1 & 112 & 33.7 \\
\hline j) Physically active & 275 & 82.8 & 19 & 5.7 & 38 & 11.4 \\
\hline k) Taking OCP & 68 & 20.5 & 136 & 41 & 128 & 38.6 \\
\hline \multicolumn{7}{|l|}{$\begin{array}{l}\text { 3. Methods of breast cancer } \\
\text { screening }\end{array}$} \\
\hline a) Breast Self-Examination & 318 & 95.8 & 11 & 3.3 & 3 & 0.9 \\
\hline b) Clinical Breast Examination & 296 & 89.2 & 24 & 7.2 & 12 & 3.6 \\
\hline c) Pap smear test & 183 & 55.1 & 101 & 30.4 & 48 & 14.5 \\
\hline d) Mammography & 199 & 59.9 & 30 & 9 & 103 & 31 \\
\hline \multicolumn{7}{|l|}{$\begin{array}{l}\text { 4. Best time for breast cancer } \\
\text { screening }\end{array}$} \\
\hline a) Duringmenses & 152 & 45.8 & 44 & 13.3 & 136 & 41 \\
\hline b) After menses & 199 & 59.9 & 25 & 7.5 & 108 & 32.5 \\
\hline c) Same date every month (for & 111 & 33.4 & 31 & 9.3 & 190 & 57.2 \\
\hline
\end{tabular}

5. Places for breast cancer screening

$\begin{array}{lcccccc}\text { a) Home } & 280 & 84.3 & 35 & 10.5 & 17 & 5.1 \\ \text { b) Government clinics } & 310 & 93.4 & 11 & 3.3 & 11 & 3.3 \\ \text { c) Private clinics } & 313 & 94.3 & 3 & 0.9 & 16 & 4.8 \\ \text { d) Government hospitals } & 312 & 94 & 4 & 1.2 & 16 & 4.8 \\ \text { e) Private hospitals } & 307 & 92.5 & 5 & 1.5 & 20 & 6 \\ \text { 6. Presence of abnormal } & 138 & 41.6 & 143 & 43.1 & 51 & 15.4 \\ \text { lumpis) in the breast } & & & & & & \\ \text { means cancer } & & & & & \end{array}$

7. Recommendation for

breast cancer screening by $\mathrm{MOH}$

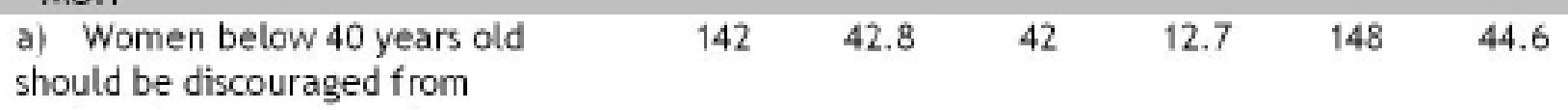




\begin{tabular}{|c|c|c|c|c|c|c|}
\hline $\begin{array}{l}\text { b) Women aged } 40-49 \text { years old } \\
\text { should be screened annually }\end{array}$ & 222 & 66.9 & 24 & 7.2 & 86 & 25.9 \\
\hline $\begin{array}{l}\text { c) Women aged } 50-75 \text { years old can } \\
\text { be screened annually or biennially }\end{array}$ & 148 & 44.6 & 37 & 11.1 & 147 & 44.3 \\
\hline $\begin{array}{l}\text { d) Women above } 75 \text { years old do } \\
\text { not need screening }\end{array}$ & 129 & 38.9 & 40 & 12 & 163 & 49.1 \\
\hline \multicolumn{7}{|l|}{$\begin{array}{l}\text { 8. Treatment cptions for } \\
\text { breast cancer patients }\end{array}$} \\
\hline $\begin{array}{l}\text { a) Breast cancer is incurable even if } \\
\text { detected in the early stage }\end{array}$ & 302 & 91 & 12 & 3.6 & 18 & 5.4 \\
\hline b) Radiotherapy & 178 & 53.6 & 36 & 10.8 & 118 & 35.5 \\
\hline c) Chemotherapy & 268 & 80.7 & 12 & 3.6 & 52 & 15.7 \\
\hline d) Lumpectomy & 308 & 92.8 & 8 & 2.4 & 16 & 4.8 \\
\hline e) Mastectomy & 294 & 88.6 & 14 & 4.2 & 24 & 7.2 \\
\hline f) Hormone therapy & 122 & 36.7 & 51 & 15.4 & 159 & 47.9 \\
\hline g) Breast cancer is self-limiting & 296 & 89.2 & 4 & 1.2 & 32 & 9.6 \\
\hline
\end{tabular}

The distribution and collection of the questionnaires were followed up three times in every two days before the subjects were considered as non-respondents.

The data collected was analysed using SPSS 12.0 for Windows. Descriptive and analytical methods were used to interpret the result. To test for associations between the independent and dependent variables, statistical tests such as Chi-square Test and Fisher's Exact Test were used. All tests were significant at $\mathrm{p}<0.05$.

Approval from the Ethical Committee of Faculty of Medicine and Health Sciences was obtained. Permission was also obtained from the various departments from which the sample was derived before proceeding with the data collection. Written personal consent was obtained from each respondent. The information given by the respondents was strictly confidential. The information was used exclusively for this research. The identities of the respondents were kept anonymous.

\section{RESULTS}

Three hundred and ninety-four female staffs were identified in the selected departments. Three hundred and thirty two female staff responded to the study with a response rate of $84.3 \%$. Table 1 shows the socioeconomic characteristics and family history of breast cancer of the female staff in the university. The mean age of respondents was 34.7 years and the majority of the respondents were in the age group of $30-50$ years. There were $72.6 \%$ of the respondents who were non-academic staffs. Out of 332 respondents, $321(96.7 \%)$ of them were Malays, 323 (97.3\%) were Muslims and 110 (33.2\%) were married. About $26.3 \%$ of the respondents had Bachelor's degree. Most of the respondents $(18.1 \%)$ had monthly family income more than RM 5000.00 . Only $10.6 \%$ had family history of breast cancer.

Table 2 shows that $84.6 \%$ of the respondents knew that the presence of lumps in the breast is one of the symptoms of breast cancer, but only $46.1 \%$ of the respondents knew that puckering of the skin of the breast is a symptom of breast cancer. Regarding the risk factors of breast cancer, $86.4 \%$ of the respondents answered correctly that a positive family history is one of the risk factors. However, $41.0 \%$ of the respondents did not have the knowledge of taking oral contraceptive pills as a risk factor. Although almost all the respondents knew that breast self-examination and clinical breast examination are the methods of breast cancer screening, only $59.9 \%$ knew that mammography is a breast cancer screening method. Majority of the respondents knew breast cancer screening is available.

The total score for knowledge on breast cancer screening was 41 , the highest score of the respondents was 39 and the lowest score was 3 (mean score was 25.77 \pm 6.38 and the median score was 27). Among the 332 respondents, 169 (50.9\%) of them had good knowledge, while $163(49.1 \%)$ of them had poor knowledge. Table 2. Distribution of correct and wrong answers on knowledge of breast cancer screening among the respondents.

Table 3 shows that there were significant association between the level of knowledge of breast cancer screening and occupational status $\left(x^{2}=9.736, p=\right.$ $0.002)$, monthly family income $\left(\chi^{2}=23.889, p=0.000\right)$ and educational level $\left(\chi^{2}=23.564, p=0.000\right)$.

Table 4 displays that most of the respondents $(92.2 \%)$ received the information from mass media (e.g. television, radio, newspaper and magazine). Other main sources of information were health promotion activities $(73.8 \%)$, health education brochures $(73.8 \%)$, books $(69.6 \%)$, internet $(66.9 \%)$, and friends $(64.8 \%)$. Table 5 shows that 237 (71.4\%) participants preferred to get the information from health team. Other pref- 
Table 3. Associations between level of knowledge and socioeconomic characteristics and family history of breast cancer among the respondents

\begin{tabular}{|c|c|c|c|c|c|}
\hline \multirow{3}{*}{ Socioeconomic status } & \multicolumn{2}{|c|}{ High knowledge } & \multicolumn{2}{|c|}{ Low knowledge } & \multirow{3}{*}{$\chi^{2}$} \\
\hline & & & & & \\
\hline & $\mathbf{n}$ & $\%$ & $\mathbf{n}$ & $\%$ & \\
\hline \multicolumn{6}{|l|}{ 1. Age $(n=331)$} \\
\hline$<30$ years & 63 & 48.1 & 68 & 51.9 & \multirow{3}{*}{$\begin{array}{l}0.616 \\
0.735\end{array}$} \\
\hline $30-50$ years & 94 & 52.5 & 85 & 47.5 & \\
\hline$>50$ years & 11 & 52.4 & 10 & 47.6 & \\
\hline \multicolumn{6}{|l|}{ 2. Race $(n=332)$} \\
\hline Malays & 163 & 50.8 & 158 & 49.2 & \multirow{2}{*}{$\begin{array}{r}0.060 \\
0.525^{\mathrm{a}}\end{array}$} \\
\hline Non-Malays & 6 & 54.5 & 5 & 45.5 & \\
\hline \multicolumn{6}{|l|}{ 3. Religion $(n=332)$} \\
\hline Muslim & & & & & \multirow{3}{*}{$\begin{array}{c}0.154 \\
0.477^{a}\end{array}$} \\
\hline & 165 & 51.1 & 158 & 48.9 & \\
\hline Non-Muslim & 4 & 44.4 & 5 & 55.6 & \\
\hline \multicolumn{6}{|l|}{ 4. Marital status $(n=331)$} \\
\hline Married & 116 & 54.2 & 98 & 45.8 & \multirow[t]{2}{*}{$\begin{array}{c}2.884 \\
0.057^{\mathrm{a}}\end{array}$} \\
\hline Single/ Others & 52 & 44.4 & 65 & 55.6 & \\
\hline \multicolumn{6}{|l|}{ 5. Occupational status $(n=332)$} \\
\hline Academic staff & 59 & 64.8 & 32 & 35.2 & \multirow[t]{2}{*}{$\begin{array}{r}9.736 \\
0.001^{a}\end{array}$} \\
\hline Non-academic staff & 110 & 45.6 & 131 & 54.4 & \\
\hline \multicolumn{6}{|l|}{ 6. Monthly family income $(n=332)$} \\
\hline$<$ RM1000 & 11 & 26.2 & 31 & 73.8 & \multirow[t]{6}{*}{$\begin{array}{l}23.889 \\
0.000\end{array}$} \\
\hline RM1000-RM2000 & 39 & 41.9 & 54 & 58.1 & \\
\hline RM2001-RM3000 & 34 & 52.3 & 31 & 47.7 & \\
\hline RM3001-RM4000 & 27 & 62.8 & 16 & 37.2 & \\
\hline RM4001-RM5000 & 21 & 72.4 & 8 & 27.6 & \\
\hline$>$ RM5000 & 37 & 61.7 & 23 & 38.3 & \\
\hline \multicolumn{6}{|l|}{ 7. Educational level $(n=331)$} \\
\hline Primary and secondary education & 35 & 33.3 & 70 & 66.7 & \multirow[t]{5}{*}{$\begin{array}{c}23.564 \\
0.000\end{array}$} \\
\hline Diploma & 22 & 46.8 & 25 & 53.2 & \\
\hline Bachelor & 52 & 59.8 & 35 & 40.2 & \\
\hline Master & 45 & 65.2 & 24 & 34.8 & \\
\hline $\mathrm{PhD}$ & 15 & 65.2 & 8 & 34.8 & \\
\hline \multicolumn{6}{|c|}{ 8. Family history of breast cancer $(n=329)$} \\
\hline Yes & 20 & 57.1 & 15 & 42.9 & \multirow[t]{2}{*}{$\begin{array}{l}0.523 \\
0.294^{\mathrm{a}}\end{array}$} \\
\hline No & 149 & 50.7 & 145 & 49.3 & \\
\hline
\end{tabular}

aFisher's Exact Test 
Table 4. Sources of information on breast cancer screening among the respondents

\begin{tabular}{lcc} 
Sources of information & $\mathbf{n}$ & $\%$ \\
\hline 1. Mass media & 306 & 92.2 \\
\hline 2. Health promotion activities & 245 & 73.8 \\
\hline 3. Health education brochures & 245 & 73.8 \\
\hline 4. Books & 231 & 69.6 \\
\hline 5. Internet & 222 & 66.9 \\
\hline 6. Friends & 215 & 64.8 \\
\hline 7. Health team & 195 & 58.7 \\
\hline 8. Family members & 117 & 35.2 \\
\hline 9. Others & 7 & 2.1 \\
\hline
\end{tabular}

Table 5. Preferred sources of information on breast cancer screening

\begin{tabular}{|ccc|}
$\begin{array}{l}\text { Sources of information } \\
\text { 1. Health team }\end{array}$ & $\mathbf{n}$ & $\%$ \\
\hline $\begin{array}{l}\text { 2. Health education } \\
\text { brochures }\end{array}$ & 182 & 71.4 \\
\hline $\begin{array}{l}\text { 3. Mass media } \\
\text { 4. Internet }\end{array}$ & 167 & 50.3 \\
\hline $\begin{array}{l}\text { 5. Health promotion } \\
\text { activities }\end{array}$ & 164 & 49.4 \\
\hline $\begin{array}{l}\text { 6. Books } \\
\text { 7. Friends }\end{array}$ & 157 & 47.3 \\
\hline 8. Family members & 113 & 34 \\
\hline 9. Others & 72 & 21.7 \\
\hline
\end{tabular}

erable sources of information were health education brochures, mass media, internet and health promotion activities, which were $54.8 \%, 50.3 \%, 49.4 \%$, and $47.3 \%$, respectively.

\section{DISCUSSION}

Among the 332 female staff who participated in this study, 169 (50.9\%) had good knowledge, while 163 (49.1\%) had poor knowledge. The prevalence of good knowledge among the respondents was $50.9 \%$. In comparison, the prevalence of having satisfactory knowledge on breast self-examination among 122 working women in Cairo, Egypt, in 2001 was only $11.5 \%$ while another study among Chinese-American women also showed that the level of knowledge on breast cancer screening was poor.7,8 The prevalence of good knowledge among respondents in this study was higher compared to other studies. The difference is probably because this study was conducted in a university setting. Moreover, $68.5 \%$ of the respondents in this study had tertiary level education.

The findings of this study indicated that knowledge on breast cancer screening was significantly associated with occupational status $\left(x^{2}=9.736, p=0.001\right)$, monthly family income $\left(\chi^{2}=23.889, p=0.000\right)$, and edu- cation level $\left(x^{2}=23.564, p=0.000\right)$. As this research was conducted in a university setting, there was not much variation in the type of occupation among its staff. Therefore, the occupation status was grouped into two large groups of academic and non-academic staffs. More than half of the academic staff $(64.8 \%)$ has high knowledge on breast cancer screening compared to $45.6 \%$ of non-academic staff. It may be because the latest information on breast cancer screening was better circulated among the academic staff than the non-academic staff, as a result of higher education level among them. Comparison with other studies was lacking due to limited researches in the published material in similar settings.

Monthly family income was found to be significantly associated with the level of knowledge on breast cancer screening. This finding is consistent with other studies. In a study done in 2003 among urban African American women, annual household income was significantly associated with knowledge about mammography, breast cancer and its treatment $(\mathrm{p}<0.01) .10 \mathrm{It}$ is also similar to another study done in 2004 among female Chinese immigrants in New York where women with a higher income were twice as likely to have higher knowledge of breast cancer risk $(\mathrm{OR}=2.12$, $\mathrm{p}=0.014) .{ }^{11}$

In this study, the association between the level of knowledge and educational level was found to be significant $\left(x^{2}=23.564, p<0.001\right)$. This finding was consistent with the study conducted in Medical and Nursing Faculties of Aim Shams University, which showed that university graduates had a higher percentage of satisfactory knowledge (25.4\%) than the secondary school graduates (7.8\%).8 Also, a study among Appalachian women showed that there were higher knowledge scores for those having at least some college education $(p=0.003) .6$ This relationship was further supported by a study among African-American in three rural counties in Georgia, which were named group $A, B$ and C. A significant difference among groups on education was reported $\left(\chi^{2}=29.26, p=0.001\right)$, and more women in group $A$ and $B$ reached higher levels of education than women in group $C$. When assessing the knowledge of breast cancer, more women in group $\mathrm{A}$ and $B$ thought that pain, soreness, and burning in the breast were symptomatic of breast cancer compared to women in group $C\left(x^{2}=12.24, p=0.002\right)$. Women in group $C$ were less likely to identify discharge from the nipple $\left(\chi^{2}=10.52, p=0.005\right)$, swelling or enlargement of the breast $\left(x^{2}=8.95, p=0.011\right)$, changes in the shape of the breast or nipple $\left(\chi^{2}=14.22, p=0.001\right)$, and discoloration $\left(\chi^{2}=15.73, p<0.001\right)$ as signs and symptoms of breast cancer than participants in groups $A$ and $B .{ }^{12}$

In this study, Table 4 displays that most of the respondents received breast cancer screening information from mass media $(92.2 \%)$, followed by health promotion activities $(73.8 \%)$ and health education brochures (73.8\%). However, a study among Filipino-American women documented that their most commonly reported source of breast cancer screening information 
was healthcare professional (61\%) followed by printed media (43\%), television (20\%), family and friends $(12.5 \%)$, health education programs $(9 \%)$, and the internet (2\%).14 Meanwhile, another study conducted in the Medical and Nursing Faculties of Ain Shams University showed that peer group (47.8\%) was the main source of breast cancer screening information. ${ }^{8}$

Table 5 shows that 237 (71.4\%) participants preferred to receive breast cancer screening information from the health team. Other preferred sources of information were health education brochures, mass media, internet and health promotion activities, which were $54.8 \%, 50.3 \%, 49.4 \%$, and $47.3 \%$, respectively. These findings were inconsistent with the results in the study among Korean American women which showed that the respondents preferred to receive such information by mail $(76.4 \%)$, telephone $(34.1 \%)$, and education programmes $(35.8 \%) .^{13}$

As this study was conducted in semester break April 2005 many of the female staffs were not available during the period of data collection because they were away for learning visits, seminars, training or holiday. Therefore, this study is expected to be more successful if it was conducted during the semester period. As this research uses a self-administered questionnaire, the message in the questionnaire might be misunderstood and therefore information bias cannot be excluded.

\section{CONCLUSION}

As a conclusion, $50.9 \%$ of respondents had high knowledge of breast cancer screening. There was significant association between the level of knowledge of breast cancer screening and occupational status, monthly family income and educational level. Majority of the respondents considered the mass media as a major source of information on breast cancer screening while the most preferred source of information was from the health team itself. However, the health team was considered only as the seventh major source of information. Therefore, the health team in Malaysia should play a more active role in educating women regarding breast cancer and recommend appropriate screening for women, especially women at risk.

\section{REFERENCES}

1. McPherson K, Steel C M, Dixon J M. Clinical review on $A B C$ of breast diseases: Breast can cer - epidemiology, risk factors, and genet ics.Brit Med J 2000; 321:624-8.

2. National Cancer Registry, Malaysia, Second Report, 2004. Available at: http://www.crc. gov.my/ncr/documents/NCR_2nd_Report/ Chapter2.pdf. Accessed February 2, 2005.

3. Malaysian Medical Association: Cancer in Malaysia - There is light at the end of the tun nel, 1998. Available at: http://www.mma. org.my/info/5_cancer_03.htm. Accessed Feb ruary 2, 2005.

4. Ministry of Health, Malaysia: Clinical Prac tice Guidelines - Management of Breast Cancer. Dec 2002.

Available at: http://www. acadmed.org.my/cpg/ CPG on Manage ment of Breast Cancer. Clinical Prac tice Guide lines Management of Breast Cancer Malaysia. Accessed March 23, 2005.

5. Narimah A, Rugayah B, Tahir A, Maimunah $A H$. The Second National Health and Morbid ity Survey (NHMS II) 1996. Institute of Public Health, Ministry of Health Malaysia, 1997.

6. Nan Leslie S, Pamela D, Suzanne G, et al. Knowledge, attitudes, and practices sur rounding breast cancer screening in educat ed Appalachian women. Oncol Nurs Forum 2003; 30: 659-67.

7. Elena YSH, Katherine KK, Edwin $\mathrm{CH}$, Ruth $A B$. Breast and cervical cancer screening among ChineseAmerican women. Cancer Pract 2001; 9:81-91.
8. Nadia YS, Magda AA. Effect of breast self examination training programme on knowl edge, attitude and practice of a group of working women. J Egypt Nat Cancer Inst 2000; 12:105-15.

9. Lwanga SK, Lameshow S. Sample size deter mination in health sciences. A Practical Man ual, WHO Geneva, 1991.

10. Lukwago SN, Kreuter MW, Holt CL, et al. So ciocultural correlates of breast cancer knowl edge and screening in urban African-Ameri can women. Am J Pub Health 2003; 93:1271-4.

11. Chen WT, Bakken S. Breast cancer knowl edge assessment in female Chinese immigrants in New York. Cancer Nurs 2004; 27:407-12.

12. Cecelia GG, Larry B, Lee C, Daniel B. The ef fect of breast cancer screening messages on knowledge, attitudes, perceived risk, and mammography screening of African-Amer ican women in the rural south. Oncol Nurs Fo rum 2004; 31:801-8.

13. Georgia SR, Lisa RT, Celine MK, Emily N. Ko rean women: Breast cancer knowledge, atti tudes and behaviors. BMC Public Health 2001; 1:7. Available at http: / /www.biomed central.com/1471-2458/1/7. Accessed Febru ary 2, 2005.

14. Ko C M, Sadler GR, Ryujin L, Dong A. FilipinoAmerican Women's Breast Cancer Knowl edge, Attitudes and Screening Be haviours. BMC Public Health 2003; 3:27. Avail able at http://www.biomedcentral. com/1471-2458/3/27. Accessed February 2, 2005. 
IMJM THE INTERNATIONAL MEDICAL JOURNAL MALAYSIA

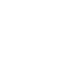

